\title{
OBTAINING OF $\beta$-LACTOGLOBULIN BY GEL FILTRATION OF COW MILK WHEY
}

\author{
Volodymyr Yukalo \\ Department of Food Biotechnology and Chemistry \\ Ternopil Ivan Puluj National Technical University \\ 56 Ruska str., Ternopil, Ukraine, 46001 \\ biotech@tu.edu.te.ua \\ Kateryna Datsyshyn \\ Department of Food Biotechnology and Chemistry \\ Ternopil Ivan Puluj National Technical University \\ 56 Ruska str., Ternopil, Ukraine, 46001 \\ katkostyuk3103@gmail.com \\ Liudmyla Storozh \\ Department of Food Biotechnology and Chemistry \\ Ternopil Ivan Puluj National Technical University \\ 56 Ruska str., Ternopil, Ukraine, 46001 \\ storozh@tntu.edu.ua
}

\begin{abstract}
Milk whey proteins carry out a number of important biological functions and also they are precursors of many biologically active peptides (antihypertensive peptides, antagonists of opioid receptors, regulators of intestinal motility, immunomodulatory, anti-microbial and anti-cancer peptides, appetite regulators and so on.). An important stage in natural bioactive peptides obtaining from milk whey proteins is the isolation of homogeneous proteins-precursors. Considering the significant difference in the molecular masses of whey proteins, a promising method for their selection is gel filtration. The purpose of the research was the fractionation of bioactive peptides precursors from milk whey using gel filtration on Sephadex G-150. The whey was obtained from fresh skimmed milk after isoelectric precipitation of casein. Gel filtration was carried out on the columns from a liquid chromatography kit by the "Reanal" company. The fractional composition and the degree of homogeneity of milk whey proteins were determined by disc-electrophoresis in the plates of a polyacrylamide gel. A repeated gel filtration of fractions from the chromatographic peaks, separated into sections, was performed to increase the fractionation efficiency. While choosing a dextran gel for gel filtration of precursors of biologically active peptides from milk whey proteins, we have taken into account the range of their molecular weights (from 10000 to $150000 \mathrm{Da}$ ), the ability to form supramolecular structures $(\beta-\mathrm{LG})$, as well as the previously obtained results of gel filtration. As a result, it was shown that repeated gel filtration of milk whey on Sephadex G-150 allows efficiently fractionate the proteins-precursors of bioactive peptides. The range of peptides and proteins molecular weights that can be fractionated on this Sephadex is from 5000 to $300000 \mathrm{Da}$. The usage of repeated gel filtration on Sephadex G-150 with the chromatogram separation into sectors allows to effectively fractionate proteins-precursors of bioactive peptides from milk whey. In particular, homogeneous $\beta$-lactoglobulin (degree of homogeneity $>95 \%$ ) and partially purified $\alpha$-lactalbumin, as well as a group of immunoglobulins and a proteose-peptone fraction were obtained.
\end{abstract}

Keywords: milk whey proteins, $\beta$-lactoglobulin, gel filtration, disc-electrophoresis.

\section{Introduction}

The main proteins of milk whey $\beta$-lactoglobulin $(\beta-\mathrm{LG}), \alpha$-lactalbumin $(\alpha-\mathrm{LA})$, lactoferrin (LF), blood serum albumin (BSA) and possibly immunoglobulin (IG) belong to the precursors of biologically active peptides (BAP) [1]. Many natural BAP are in the composition of milk whey proteose-peptone fraction (PPF) [2]. Most of the BAP can be formed in the processes of $\beta$-LG proteolysis. About a half of amino acid residues from its primary structure are a part of the composition of different BAP. Bioactive peptides from $\beta$-LG can influence the cardiovascular system (antihypertensive peptides), cholesterol metabolism (hypocholesterolemic peptides), and intestinal 
motility. In $\alpha$-LA almost $40 \%$ of amino acid residues form BAP, which often exhibit bactericidal, immunomodulatory and antihypertensive effects [2]. The bactericidal action is characteristic for bioactive peptides from lactoferrin $(\sim 10 \%$ amino acid residues) [3]. The great heterogeneity of milk whey proteins and the considerable variety of BAP that can be formed from them are the main deterrent factors for the use of this phenomenon in the creation of functional ingredients and food products. Therefore, creating of accessible and effective methods for obtaining homogeneous precursors of BAP from milk whey is relevant.

Existing methods of milk whey proteins fractionating are based on differences in their structure and properties. These are the ability to dissolve in the presence of salts (differential precipitation) [4, 5], resistance to heating (thermocoagulation) [4], resistance to proteolytic enzymes (selective proteolysis) [6], differences in molecules charges (ion exchange chromatography) [4, 7]. But for industrial using these methods are either too complicated or lead to irreversible changes in the structure and chemical composition of whey proteins. This makes it impossible to obtain natural BAP from them.

In this regard, the method of gel filtration attracts attention. It allows carrying out the protein molecules fractionation by the molecular masses in a wide range of conditions [8]. The native structure and chemical composition of proteins are saved in this case. The precursors of BAP from whey proteins significantly differ in molecular weights. This is an important prerequisite for their efficient fractionation in the process of gel filtration.

While choosing a dextran gel for the gel filtration of BAP precursors from whey proteins, the range of their molecular weights, the ability to form supramolecular structures ( $\beta$-LG) was taken into account by the authors. Sephadexes G-100 and G-150 with a certain approximation may be used for the peptides and proteins fractionation with such ranges of molecular weights. Previous studies have shown that gel filtration is appropriate for the obtaining of milk whey total protein, separate groups of whey proteins and a mixture of low molecular weight components of the proteose-peptone fraction [9]. At the same time, it was ineffective in the obtaining of homogeneous proteins from milk whey. Repeated gel filtration and dividing the chromatographic peaks into the sectors for the proteins fractions selection can be used to increase the resolution of gel filtration. Such an approach has given good results in the obtaining of individual proteins from casein complex [10]. Also, the results of repeated gel filtration of milk whey proteins on Sephadex G-100, previously carried out at the Department of Food Biotechnology and Chemistry of Ternopil Ivan Puluj National Technical University (Ukraine) were taken into account [11]. According to this, Sephadex G-150 was selected for repeated gel filtration. The range of peptides and proteins molecular masses that can be fractionated on this Sephadex is from 5000 to $300,000 \mathrm{Da}$. The aim of the study was to isolate $\beta$-LG from milk whey by repeated gel filtration on Sephadex G-150, which would allow to save its structure and to use it as a precursor of biologically active peptides.

\section{Materials and methods}

The whey was obtained from fresh cow skimmed milk $\left(18-19{ }^{\circ} \mathrm{T}\right)$ by precipitation of caseins at isoelectric point ( $\mathrm{pH} 4.6)$. The whey was purified from low molecular weight compounds and transferred to the appropriate electrophoresis buffer by gel filtration on the Sephadex G-25 of "Pharmacia" (Sweden) company while using in electrophoretic researches. Gel filtration was performed on columns $(2 \times 35 \mathrm{~cm})$ from the liquid chromatography kit of "Reanal" (Hungary) company. The amount of milk whey sample was $5 \mathrm{~cm}^{3}$. The elution speed was set at $20 \mathrm{~cm}^{3} / \mathrm{h}$. For the construction of the chromatogram, the optical density in the fractions was determined on a spectrophotometer SF-46 ("LOMO", Russia) ( $\lambda=280 \mathrm{~nm}$ ). The gel filtration on the Sephadex G-150 from "Pharmacia" company was carried out on columns $(1.5 \times 70 \mathrm{~cm})$ from the "Reanal" company liquid chromatography kit. The elution speed was set at $20 \mathrm{~cm}^{3} / \mathrm{h}$. The volume of selected fractions was $4 \mathrm{~cm}^{3}$.

The fractional composition and homogeneity of milk whey proteins were analyzed by disc-electrophoresis in the plates of polyacrylamide gel (PAG). Davis disc-electrophoresis analytical system for acidic and neutral proteins in the native conditions was chosen as the basis [12]. Gels were stained in $0.5 \%$ Amido black 10B solution and fixed in $7 \%$ acetic acid. Electrophoresis was 
performed on the apparatus of Studier type [13]. Stacking and separating PAGs were prepared as shown in Tables 1, 2.

Table 1

The composition of the separating PAG

\begin{tabular}{cccc}
\hline Solutions & $\begin{array}{c}\text { Part of the solution in } \\
\text { the PAG (volume) }\end{array}$ & Component & Amount \\
\hline Gel components & 2 & acrylamide & $15 \mathrm{~g}$ \\
& N,N'methylenebisacrylamide & $0,4 \mathrm{~g}$ \\
to $50 \mathrm{~cm}^{3}$ & $24 \mathrm{ml}$ & $18,3 \mathrm{~g}$ \\
Buffer for gel and \\
catalyst
\end{tabular}

Table 2

The composition of the stacking PAG

\begin{tabular}{|c|c|c|c|}
\hline Solutions & $\begin{array}{l}\text { Part of the solution in } \\
\text { the PAG (volume) }\end{array}$ & Component & Amount \\
\hline \multirow{3}{*}{ Gel components } & \multirow{3}{*}{2} & acrylamide & $5 \mathrm{~g}$ \\
\hline & & N,N'methylenebisacrylamide & $1,25 \mathrm{~g}$ \\
\hline & & water & to $50 \mathrm{~cm}^{3}$ \\
\hline \multirow{3}{*}{ Buffer for gel } & \multirow{3}{*}{1} & $1 \mathrm{H} \mathrm{H}_{3} \mathrm{PO}_{4}$ & $12,8 \mathrm{ml}$ \\
\hline & & tris (hydroxymethyl)aminomethane & $2,85 \mathrm{~g}$ \\
\hline & & water & to $50 \mathrm{~cm}^{3}$ \\
\hline \multirow{3}{*}{$\begin{array}{l}\text { Initiator and catalyst } \\
\text { solution }\end{array}$} & \multirow{3}{*}{1} & ammonium persulphate & $\begin{array}{l}\text { are selected } \\
\text { experimentally }\end{array}$ \\
\hline & & $\mathrm{N}, \mathrm{N}, \mathrm{N}^{\prime}, \mathrm{N}^{\prime}$ tetramethylethylenediamine & $0,115 \mathrm{ml}$ \\
\hline & & water & to $5 \mathrm{ml}$ \\
\hline \multirow{2}{*}{ Solution_saccharose } & \multirow{2}{*}{4} & saccharose & $20 \mathrm{~g}$ \\
\hline & & water & to $50 \mathrm{~cm}^{3}$ \\
\hline
\end{tabular}

Also, an electrode buffer was prepared as shown in Table 3. Before use, the buffer was diluted 10 times with distilled water.

Table 3

The composition of the electrode buffer

\begin{tabular}{ccc}
\hline Solution & Buffer components & Amount \\
\hline & tris (hydroxymethyl) aminomethane & $6 \mathrm{~g}$ \\
Electrode buffer $(\mathrm{pH} 8,3)$ & glycine & $28,8 \mathrm{~g}$ \\
& water & to $1000 \mathrm{ml}$
\end{tabular}

Quantitative processing of electrophoregrams was carried out by using the image reading function imread [14]. 


\section{Experiments}

The following experiments were carried out successively for the $\beta$-lactoglobulin obtaining by repeated gel filtration:

1. Milk whey gel filtration on a column with Sephadex G-150 with the constructing of corresponding chromatogram.

2. Combining of the chromatographic fractions of three sectors $(\mathrm{A}, \mathrm{B}, \mathrm{C})$, which contain whey proteins.

3. Repeated gel filtration of combined chromatographic fractions of three sectors on a column with Sephadex G-150. The analysis of proteins composition of chromatographic fractions by disc-electrophoresis on the polyacrylamide gel plates after repeated gel filtration. Milk whey after gel filtration on a Sephadex G-25 column in an electrode buffer environment was used as a control.

4. The assessing of $\beta$-lactoglobulin fraction homogeneity was carried out by densitometry of received PAG plates.

\section{Results}

The results of milk whey gel filtration on Sephadex G-150 are shown in Fig. 1. Four peaks can be seen on the chromatogram (the second and third are joined). Four sectors A, B, C, and D had been isolated for the proteins composition analysis and selecting the combined samples for repeated gel filtration. Earlier, it was established that proteins fractions are located in sectors A, B and C [9]. Sector D contains a proteose-peptone fraction.

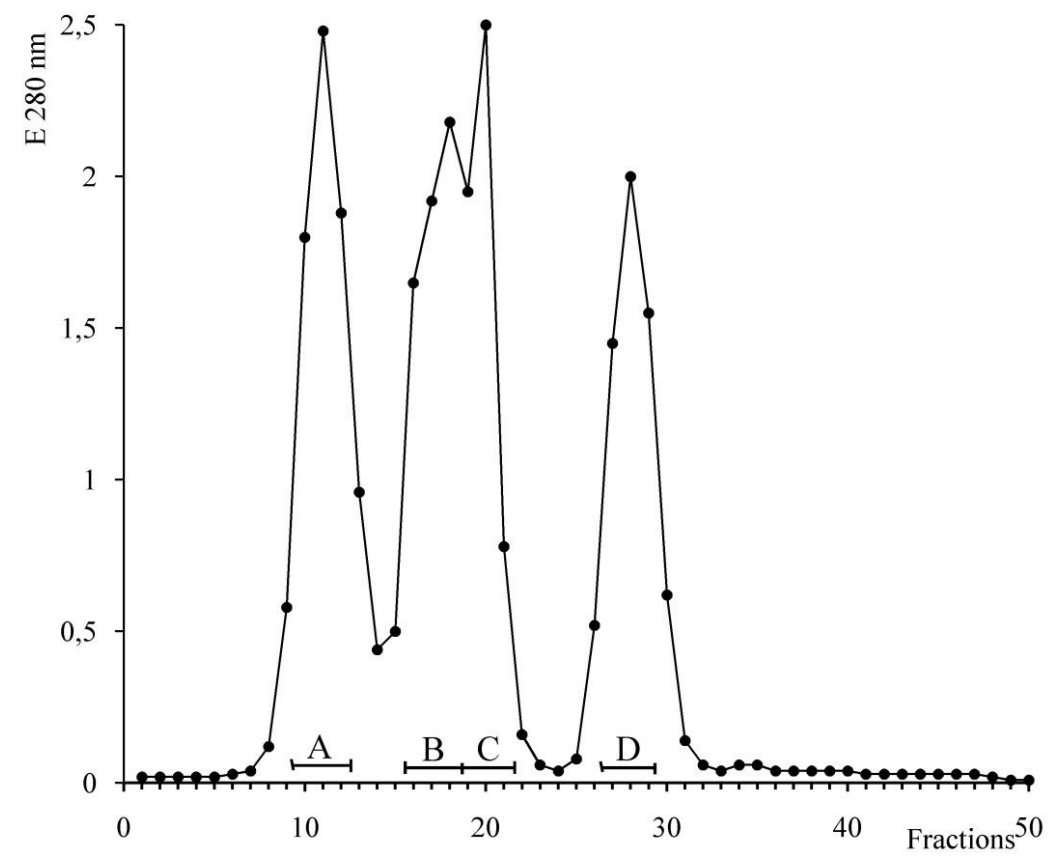

Fig. 1. Chromatogram of milk whey proteins obtained by gel filtration on Sephadex G-150

Then, combined samples from each sector (except sector D) were fractionated by repeated gel filtration on Sephadex G-150. The results of the sector A combined samples repeated gel filtration and disc-electrophoresis of the obtained fractions (I, II, III and IV) marked on the chromatogram are shown in Fig. 2.

Only IG is present in fractions I and II. Fraction III contains IG, LF and traces of BSA, and fraction IV includes BSA and traces of IG.

The best results were obtained by repeated gel filtration of the combined sample of sector B (Fig. 3). All four fractions (I, II, III, and IV) contain electrophoretically homogeneous $\beta$-LG according to the disc-electrophoresis results (Fig. 3). 
1.
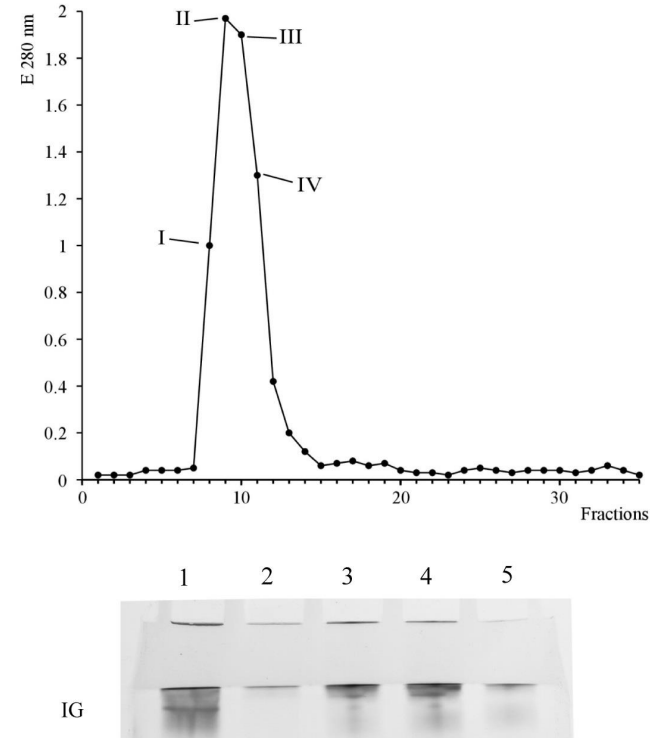

BSA

$\beta-L G$

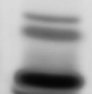

Fig. 2. Chromatogram (1) of sector A fractions repeated gel filtration on Sephadex G-150. Electrophoregram (2) of the control milk whey proteins (2.1); fractions I (2.2); fractions II (2.3); fractions III (2.4) and fractions IV (2.5) obtained after repeated gel filtration of the sector A combined sample

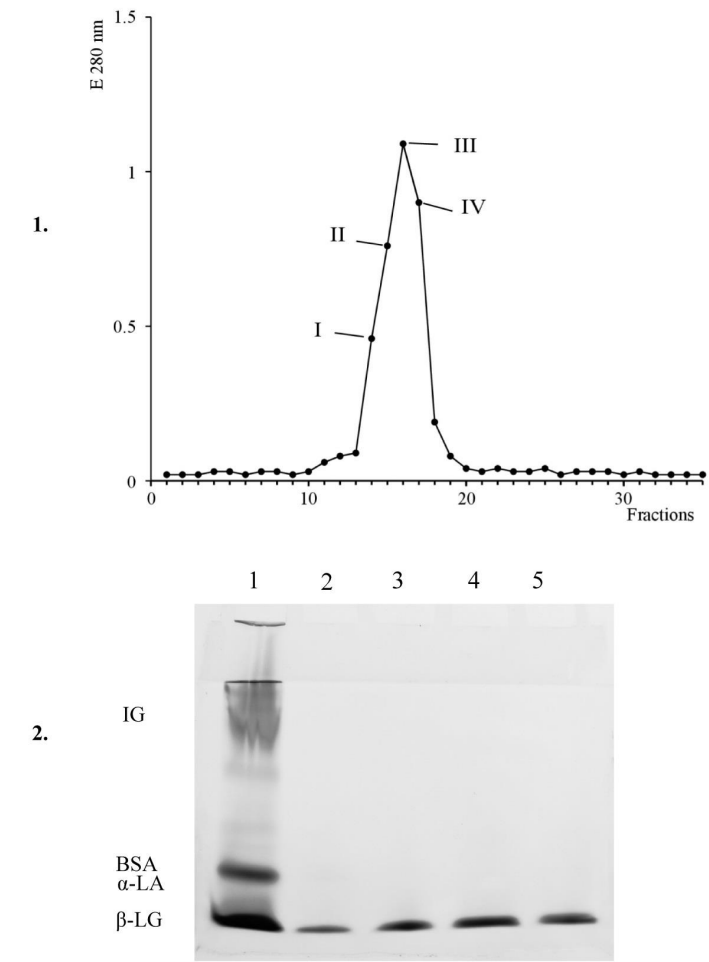

Fig. 3. Chromatogram (1) of the sector B fractions repeated gel filtration on Sephadex G-150. Electrophoregram (2) of the control milk whey proteins (2.1); fractions I (2.2); fractions II (2.3), fractions III (2.4) and fractions IV (2.5) obtained after repeated gel filtration of the sector B combined sample 
Quantitative analysis of densitograms showed that the degree of homogeneity of $\beta$-LG in selected fractions exceeds $95 \%$. It should be noted that exactly $\beta$-LG is the main precursor of BAP from milk whey proteins $[1,2]$.

After repeated gel filtration of the combined sample from the sector C (Fig. 4), one more fraction with electrophoretically homogeneous $\beta$-LG (fraction I) and two fractions (III and IV), which include the second important precursor of BAP $-\alpha$-LA with $\beta$-LG traces (tracks 4 and 5 on the electrophoregram, Fig. 4) have been obtained.
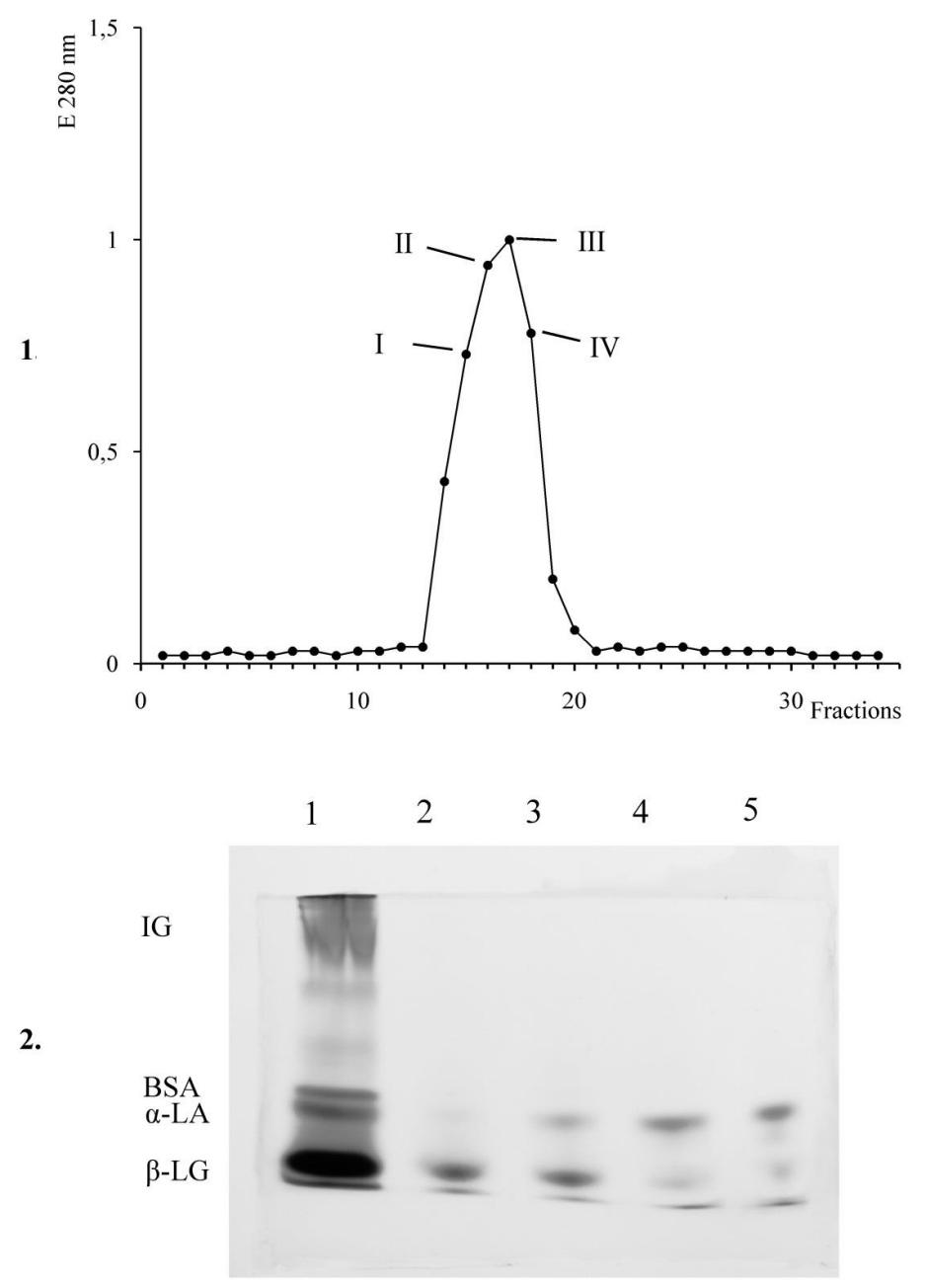

Fig. 4. Chromatogram (1) of the sector C fractions repeated gel filtration on Sephadex G-150. Electrophoregram (2) of the control milk whey proteins (2.1); factions I (2.2); fractions II (2.3); fractions III (2.4) and fractions IV (2.5) obtained after repeated gel filtration of the sector C combined sample

The results of the researches testify that the sector B, obtained after the first gel filtration, consists exclusively of the homogeneous milk whey proteins fraction $\beta$-lactoglobulin, which allows it to be used as a substrate for biologically active peptides obtaining. Other protein fractions require further purification.

\section{Conclusions}

Repeated gel filtration on Sephadex G-150 with the chromatograms separation into the sectors, comparing with the one stage gel filtration, allows fractionating the proteins-precursors of bioactive peptides from milk whey. Homogeneous $\beta$-LG (homogeneity $>95 \%$ ), as well as partially purified $\alpha-\mathrm{LA}$, immunoglobulins and proteoso-peptone fraction were obtained, as a result of the 
repeated gel filtration. Repeated gel filtration of cows' milk whey on Sephadex G-150 provides higher efficiency of the main protein fraction $\beta$-LG obtaining in a homogeneous state compared to the other types of Sephadexes (G-100, G-75). However, other important whey proteins fractions $(\alpha$-LA, BSA) require further purification. In this case, the combination of different dextran gels during carrying out of the repeated gel filtration, such as Sephadex G-150 (first gel filtration) and Sephadex G-75 (second gel filtration) may be promising.

\section{References}

[1] Park, Y. W. (Ed.) (2009). Bioactive components in milk and dairy products. Wiley-Blackwell, 426. doi: https://doi.org/10.1002/9780813821504

[2] Fox, P., Uniacke-Lowe, T., McSweeney, P., O’Mahony, J. (2015). Dairy Chemistry and Biochemistry. Springer, 584. doi: https://doi.org/10.1007/978-3-319-14892-2

[3] Oo, T. Z., Cole, N., Garthwaite, L., Willcox, M. D. P., Zhu, H. (2010). Evaluation of synergistic activity of bovine lactoferricin with antibiotics in corneal infection. Journal of Antimicrobial Chemotherapy, 65 (6), 1243-1251. doi: https://doi.org/10.1093/jac/dkq106

[4] McSweeney, P. L. H., Fox P. F. (Eds.) (2013) Advanced Dairy Chemistry. Springer, 548. doi: https://doi.org/10.1007/978-1-4614-4714-6

[5] Bonnaillie, L. M., Tomasula, P. M. (2012). Fractionation of Whey Protein Isolate with Supercritical Carbon Dioxide To Produce Enriched $\alpha$-Lactalbumin and $\beta$-Lactoglobulin Food Ingredients. Journal of Agricultural and Food Chemistry, 60 (20), 5257-5266. doi: https://doi.org/10.1021/jf3011036

[6] Konrad, G., Kleinschmidt, T. (2008). A new method for isolation of native $\alpha$-lactalbumin from sweet whey. International Dairy Journal, 18 (1), 47-54. doi: https://doi.org/10.1016/j.idairyj.2007.06.004

[7] Lozano, J. M., Giraldo, G. I., Romero, C. M. (2008). An improved method for isolation of $\beta$-lactoglobulin. International Dairy Journal, 18 (1), 55-63. doi: https://oi.org/10.1016/j.idairyj.2007.05.003

[8] Osterman, L. A. (1985). Khromatografiya belkov i nukleinovykh kislot. Moscow: Nauka, 536.

[9] Yukalo, V. G., Datsyshyn, K. Ye. (2018). Dextran gels for the exclusive chromatography of milk serum proteins. Scientific Messenger of LNU of Veterinary Medicine and Biotechnologies, 20 (85), 3-8. doi: https://doi.org/10.15421/nvlvet8501

[10] Yukalo, V. G., Storozh, L. A. (2007). Vydilennia elektroforetychno gomogennoi frakcii $\beta$-CN-5P kazeinu koroviachogo moloka. Medychna khimiya, 2, 91-95.

[11] Yukalo, V. G., Datsyshyn, K. Ye. (2018). Gel filtration of cow milk whey proteins. Food Science and Technology, 12 (4), 72-78. doi: https://doi.org/10.15673/fst.v12i4.1183

[12] Osterman, L. A. (1981). Metody issledovaniya belkov i nukleinovykh kislot: Elektroforez i ultratsentrifugirovaniye. Moscow: Nauka.

[13] Studier, F. W. (1973). Analysis of bacteriophage T7 early RNAs and proteins on slab gels. Journal of Molecular Biology, 79 (2), 237-248. doi: https://doi.org/10.1016/0022-2836(73)90003-x

[14] Yukalo, V. G., Yavorskyi, B. I., Storozh, L. A., Solovodzinska, I. Ye. (2007). Kilkisnyi elektroforetychnyi analiz bilkiv kazeinovoho kompleksu. Biolohiya tvaryn, 9 (12), 295-298. 